\title{
Nitrogen and potassium fertigation in bell pepper cultivated in greenhouse using fertigation managements ${ }^{1}$
}

\author{
Edivan S. Nunes Júnior ${ }^{2}$, José F. de Medeiros ${ }^{3}$, Francisco de A. de Oliveira ${ }^{3}$, \\ Luan A. Lima ${ }^{4}$, Francisco M. S. Bezerra ${ }^{5} \&$ Rita de C. Alves ${ }^{6}$ \\ ${ }^{1}$ Part of the Thesis of Doctorate of first author presented to Programa de Pós-Graduação in Phytotechnics of UFERSA. Project financed by CNPq \\ ${ }^{2}$ Universidade Estadual da Paraíba/Departamento de Agrárias e Exatas. Catolé do Rocha, PB. E-mail: edivanjunior@uepb.edu.br \\ ${ }^{3}$ Universidade Federal Rural do Semi-Árido/Departamento de Ciências Tecnológicas e Ambientais. Mossoró, RN. E-mail: jfmedeir@ufersa.edu.br; \\ thikaoamigao@ufersa.edu.br (Corresponding author) \\ ${ }^{4}$ Universidade Federal do Ceará/Programa de Pós-Graduação em Ciência do Solo. Fortaleza, CE. E-mail: luanefa2@yahoo.com.br \\ ${ }^{5}$ Universidade Federal do Ceará/Programa de Pós-Graduação em Engenharia Agrícola. Fortaleza, CE. E-mail: mardonnestec@hotmail.com \\ ${ }^{6}$ Universidade Estadual Paulista “Júlio de Mesquita Filho"/Faculdade de Ciências Agrárias e Veterinárias. Jaboticabal, SP. E-mail: cassiaagro-24@outlook.com
}

\section{Key words:}

Capsicum annuum L.

soil solution

salinity

ionic concentration

\begin{abstract}
A B S T R A C T
The objective of the study was to evaluate the effect of different managements of fertigation and NK doses on the production of bell pepper fruit in a protected environment. The experimental design was randomized blocks in $3 \times 5$ factorial. The treatments were formed by the combination of three managements of fertigation $\left(M_{1}\right.$ - Based on the rate of absorption; $\mathrm{M}_{2}$ - Monitoring the electrical conductivity of the soil solution; $\mathrm{M}_{3}$ - Monitoring concentrations of $\mathrm{N}$ and $\mathrm{K}$ ions in the soil solution), with five doses of $\mathrm{NK}(0,50,100,150$ and $200 \%$ of the recommended dose) and four replicates. Six samples were collected and the following variables were evaluated: number, length and diameter of fruit, pulp thickness and fruit production. Except for diameter, all variables were affected by the interaction between the studied factors. The fertigation management by monitoring and controlling the ionic concentration of the soil solution is more efficient in the production of bell pepper. The fertigation management can be performed more efficiently from the managements M2 or M3, with NK doses of 144 and 165\%, respectively, of the recommended concentration for the hydroponic cultivation of bell pepper.
\end{abstract}

\section{Palavras-chave:}

Capsicum annuum L. solução do solo salinidade concentração iônica

\section{Fertirrigação nitrogenada e potássica no cultivo do pimentão em ambiente protegido utilizando manejos de fertirrigação}

\section{R E S U M O}

Objetivou-se, com o trabalho, avaliar o efeito de diferentes manejos de fertirrigação e níveis de NK na produção de frutos de pimentão em ambiente protegido. O delineamento experimental utilizado foi em blocos casualizados em arranjo fatorial 3 x 5 em que os tratamentos foram formados pela combinação de três manejos de fertirrigação $\left(M_{1}\right.$ - Fertirrigação a partir da marcha de absorção; $M_{2}$ - Monitoramento da condutividade elétrica da solução do solo; $M_{3}$ - Monitoramento da concentração de íons de $\mathrm{N}$ e K na solução do solo), com cinco níveis de NK (0, 50, 100, 150 e 200\% da dose recomendada) e quatro repetições. Foram realizadas seis colheitas e avaliadas as seguintes variáveis: número, comprimento e diâmetro de frutos, espessura de polpa e produção de frutos. Com exceção do diâmetro, todas as variáveis foram afetadas pela interação entre os fatores estudados. O manejo da fertirrigação através do monitoramento e controle da concentração iônica da solução do solo proporcionou maior produção de frutos. A maior produtividade de frutos de pimentão pode ser obtida utilizandose fertirrigação com os manejos M2 ou M3, em níveis de NK de 144 e 165\%, respectivamente, da concentração recomendada para o cultivo de pimentão hidropônico. 


\section{INTRODUCTION}

Bell pepper (Capsicum annuum L.) is cultivated and consumed in almost all Brazil, standing out among the ten vegetables with highest economic and social importance, and its main producer is the state of São Paulo, which produced, in $2015,93,616.33 \mathrm{Mg}$ in a cultivation area of 2,320 ha (IEA, 2016).

Fertigation is one of the main technologies adopted in the vegetable production sector, especially in fruit vegetables and cultivation in protected environment. For bell pepper, specifically, potassium $(\mathrm{K})$ and nitrogen $(\mathrm{N})$ are the nutrients most extracted by the plants (Marcussi et al., 2004; Fontes et al., 2005), also standing out as the nutrients most applied via fertigation.

To obtain high yields, excessive doses of fertilizers are applied, which may lead to wastes of fertilizers and increase in soil salinity (Oliveira et al., 2013). Hence, fertigation must be managed to maintain an adequate ionic concentration in the soil solution. Recently, various studies have been conducted using the monitoring of the soil solution, regarding either electrical conductivity (Medeiros et al., 2012; Silva et al., $2013 \mathrm{~b}$ ) or the concentration of specific ions, especially $\mathrm{N}$ and K (Oliveira et al., 2013; 2015), and the results show that the use of this technology is promising.

A study conducted by Medeiros et al. (2012), with the tomato crop, found that the highest yields and efficiencies in the use of nutrients were obtained using the fertigation management based on the control and monitoring of the soil solution, demonstrating the importance of more studies on this subject.

Based on the above, this study aimed to evaluate the effect of different fertigation managements and doses of $\mathrm{N}$ and $\mathrm{K}$ on the yield of bell pepper in protected environment.

\section{Material AND Methods}

The experiment was carried out from January to July 2012, in a greenhouse, at the Department of Environmental and Technological Sciences, on the Campus of the Federal Rural University of the Semi-Arid Region - UFERSA, in Mossoró$\mathrm{RN}$, Brazil (5 $11^{\prime}$ S; 37\% $20^{\prime} \mathrm{W}$ and $18 \mathrm{~m}$ of altitude).

The experimental design was randomized blocks in a $3 \times 5$ factorial scheme, in which the treatments were formed by the combination of three fertigation managements $\left(M_{1}\right.$ - fertigation management based on the rate of absorption of the bell pepper crop; $\mathrm{M}_{2}$ - fertigation monitored by the control of the soil solution electrical conductivity; $\mathrm{M}_{3}$ - fertigation controlled by the concentration of $\mathrm{NO}_{3}^{-}$and $\mathrm{K}^{+}$ions in the soil solution) and five doses of $\mathrm{NK}(0,50,100,150$ and $200 \%$ of the recommended dose), with four replicates, totaling 60 experimental units. Each experimental unit was represented by one plastic pot with capacity for $25 \mathrm{~L}$, containing one bell pepper plant. Each pot had, at the bottom part, a drainage system formed by a $2-\mathrm{cm}$ thick layer of envelope (crushed stone + geotextile).

The utilized soil was classified as Red Yellow Argisol (EMBRAPA, 2006), collected in the layer of $0-20 \mathrm{~cm}$ in a non-cultivated area at the Campus of the UFERSA, with the following chemical characteristics: $\mathrm{pH}=6.5 ; \mathrm{OM}=10.2 \mathrm{~g} \mathrm{~kg}^{-1}$; $\mathrm{N}=0.6 \mathrm{~g} \mathrm{~kg}^{-1} ; \mathrm{P}=10.7 \mathrm{mg} \mathrm{dm}^{-3} ; \mathrm{K}=176.7 \mathrm{mg} \mathrm{dm}^{-3} ; \mathrm{Na}=35.4$ $\mathrm{mg} \mathrm{dm}{ }^{-3} ; \mathrm{Ca}=2.9 \mathrm{cmol}_{\mathrm{c}} \mathrm{dm}^{-3} ; \mathrm{Mg}=1.44 \mathrm{cmol}_{\mathrm{c}} \mathrm{dm}^{-3} ; \mathrm{H}=1.2$ $\mathrm{cmol}_{\mathrm{c}} \mathrm{dm}^{-3}$ (EMBRAPA, 1997).

The studied bell pepper variety was "All big", which belongs to the group known as "Cascadura" and is widely cultivated by the producers of Rio Grande do Norte, Pernambuco and Paraíba. Bell pepper plants were transplanted to the pots 28 days after sowing. After the seedlings were established, thinning was performed in each pot leaving the most vigorous plant.

The management $M_{1}$ used, as reference (100\%), the amount of nutrients ( $\mathrm{N}$ and $\mathrm{K}$ ) recommended for the bell pepper crop in the region of the Açu-Mossoró Agricultural Center, equivalent to 215 and $314 \mathrm{~kg} \mathrm{ha}^{-1}$, for $\mathrm{N}$ and $\mathrm{K}$, respectively, distributed according to the rate of absorption presented by Freitas (2009). The managements $M_{2}$ and $M_{3}$ used, as reference, the nutrient solution for the bell pepper crop in the NFT (Nutrient Film Technique) system, recommended by Castellane \& Araújo (1994). The proportions of NK used in the managements $M_{2}$ and $\mathrm{M}_{3}$ referred to the concentrations of these nutrients in the soil solution.

Until 15 days after transplanting, irrigation was sufficient to promote the establishment of the seedlings, and no fertigation was applied in this period. In the middle portion between the edge of the pot and the plant, at depth of $0.25 \mathrm{~m}$, a soil solution extractor and a tensiometer were installed, always on opposite sides: the former to monitor the concentration of $\mathrm{NO}_{3}{ }^{-}$and $\mathrm{K}^{+}$ ions in the soil solution and the latter to manage the irrigation of the crop during the experiment.

The soil solution was collected using extractors equipped with ceramic capsules on their bottom end and special sealing rubbers on the upper end. A tension of approximately 80 $\mathrm{kPa}$ was applied. The vacuum was applied always $12 \mathrm{~h}$ after irrigation, the solution was collected from the extractor $12 \mathrm{~h}$ after the vacuum and the soil moisture content was measured using a tensimeter.

Along the experiment, the soil solution was weekly collected and stored in plastic containers previously washed with distilled water, which were then sent to the Laboratory of Irrigation and Drainage of the UFERSA. The samples were analyzed for electrical conductivity and nitrate using a benchtop ion meter (AD 1020 ADWA) and the potassium content was analyzed using a flame photometer (DM-62 DIGIMED).

Immediately after each collection of soil solution, the tension was measured to obtain the actual soil moisture and correct the concentrations of ions for when the soil is at pot capacity. Fertigations were performed when the analyses detected reductions of $20 \%$ in relation to the concentrations of $\mathrm{NO}_{3}{ }^{-}$and $\mathrm{K}^{+}$ions and electrical conductivity used as reference at the beginning of the experiment (Medeiros et al., 2012; Oliveira et al., 2013).

The amounts of $\mathrm{N}$ and $\mathrm{K}$ applied during the entire cycle of the bell pepper crop in the different fertigation managements are presented in Table 1. The following fertilizers were used as sources of $\mathrm{N}$ and $\mathrm{K}$ : potassium nitrate, calcium nitrate, potassium chloride, monoammonium phosphate and urea.

For fertigation management, a localized irrigation system was simulated in the application of fertilizers. A 2-L PET bottle 
Table 1. Amount of NK applied during the cycle of the bell pepper crop

\begin{tabular}{|c|c|c|c|c|c|c|}
\hline \multirow{3}{*}{$\begin{array}{c}\text { NK } \\
\text { proportion } \\
(\%)\end{array}$} & \multicolumn{2}{|c|}{ Management $\mathrm{M}_{1}$} & \multicolumn{2}{|c|}{ Management $\mathrm{M}_{2}$} & \multicolumn{2}{|c|}{ Management $\mathbf{M}_{3}$} \\
\hline & $\mathrm{N}$ & K & $\mathbf{N}$ & K & $\mathbf{N}$ & K \\
\hline & \multicolumn{6}{|c|}{ g plant ${ }^{-1}$} \\
\hline 0 & 0.0 & 0.0 & 0.0 & 0.0 & 0.0 & 0.0 \\
\hline 50 & 4.0 & 6.1 & 2.2 & 3.3 & 4.1 & 4.4 \\
\hline 100 & 7.9 & 12.1 & 4.0 & 6.5 & 6.9 & 8.9 \\
\hline 150 & 11.8 & 18.2 & 7.2 & 11.7 & 9.5 & 13.1 \\
\hline 200 & 15.9 & 24.1 & 7.1 & 11.4 & 11.8 & 17.0 \\
\hline
\end{tabular}

was placed upside down above each pot and its upper section (bottom of the bottle) was cut to receive the nutrient solution. The bottom section (lid) was perforated and connected to a microtube to control the flow rate. Irrigation was performed using a drip system, with microtube emitters with mean flow rate of $1.5 \mathrm{~L} \mathrm{~h}^{-1}$, spaced by $0.50 \mathrm{~m}$, arranged in four lateral lines with 16-mm-diameter hoses.

For an adequate water supply, the soil water retention curve (Figure 1) at depth of $0.25 \mathrm{~m}$ was taken as reference, and the water depth was controlled based on the daily reading of the tensiometers installed in all treatments in each pot and at the same depth of the water calibration test. The critical moisture for irrigation was not determined; thus, irrigation was daily performed to increase soil moisture to pot capacity.

The cultivation practices, always when necessary, consisted of manual weeding, staking and spraying with foliar fertilizer, fungicide, acaricide and insecticide. Plants were trained using a trellis system formed by four concrete stakes in each block, spaced by $4 \mathrm{~m}, \mathrm{n}^{\circ} 12$ wire stretched from one end to the other in each row and suspended from $20 \mathrm{~cm}$ to the limit of $1 \mathrm{~m}$. Bell pepper plants were tied with a narrow ribbon.

Six harvests were performed from 70 days after transplanting on and the others in weekly intervals when the fruits showed shiny dark green color. The collected fruits were bagged, carefully taken to the Laboratory of Irrigation and Salinity of the UFERSA, selected, counted and evaluated for quality aspects. The following variables were analyzed: total and commercial number of fruits per plant, commercial and total production of fruits per plant (g), length, diameter and pulp thickness of commercial fruits, using a digital caliper $(\mathrm{mm})$.

The obtained data were subjected to analysis of variance, applying the $\mathrm{F}$ test and performing a follow-up analysis always

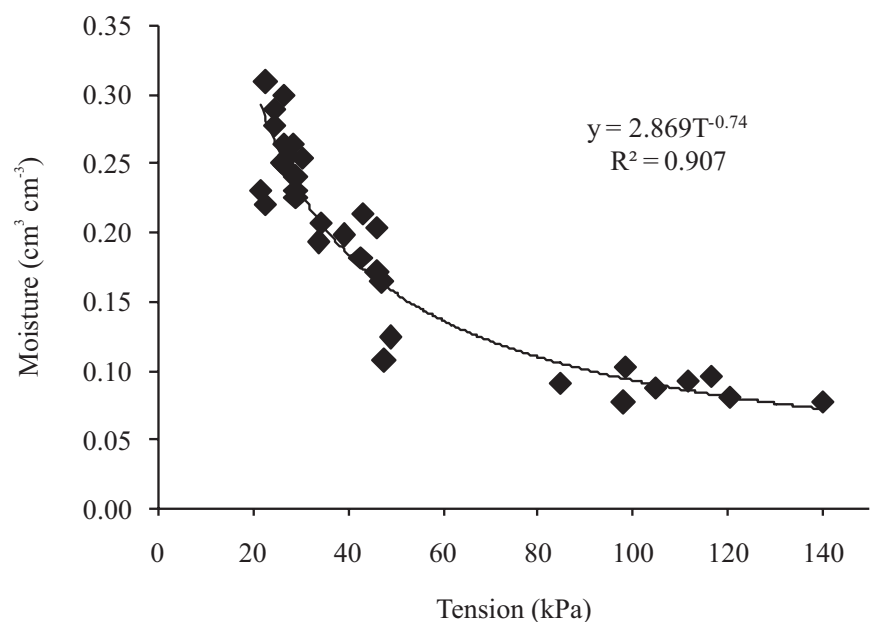

Figure 1. Water retention curve in the soil used in the experiment when the interaction was significant. The quantitative factor, relative to the doses of $\mathrm{N}$ and $\mathrm{K}$, was statistically analyzed using regression. The qualitative factor was statistically analyzed through the test of comparison of means for differentiation between fertigation managements by Tukey test $(0.05$ probability level), using the statistical software Sisvar 4.1 (Ferreira, 2008).

\section{Results AND Discussion}

The summary of the analysis of variance showed that there was significant effect at 0.01 probability level of the interaction Fertigation managements $\mathrm{x}$ NK doses on the variables total number of fruits (NF), fruit length (FL), pulp thickness (PT) and fruit production (PROD). There was no significant response for the variable fruit diameter (FD) for any of the factors, together or isolated (Table 2).

The number of fruits per plant was affected by the fertigation managements only for the proportions of 50 and $100 \%$ of NK. For the proportion of $50 \%$, the highest values occurred in managements $\mathrm{M}_{1}$ and $\mathrm{M}_{2}$, while at the proportion of $100 \%, \mathrm{M}_{2}$ promoted highest number of fruits (Table 3).

Regarding the effect of NK doses on the number of fruits per plant, for the three fertigation managements, the obtained data fitted best to a quadratic model and the highest values were obtained at the proportions equivalent to 138,123 and $166 \%$ of NK, with maximum values of 17,19 and 28 fruits per plant, for the managements $M_{1}, M_{2}$ and $M_{3}$, respectively. Comparing these values with those obtained at the lowest NK dose, there were increments of $112 \%\left(M_{1}\right), 126 \%\left(M_{2}\right)$ and $270 \%\left(\mathrm{M}_{3}\right)$ (Table 3).

These results demonstrate that the fertigation management based on the monitoring and control of the concentration of $\mathrm{NO}_{3}{ }_{3}^{-}$and $\mathrm{K}^{+}$ions promoted greater fruit setting and development, which is consistent with the results of Oliveira et al. (2013). These authors, working with the bell pepper hybrid "Atlantis", observed that the ionic concentration of the soil solution led to higher number of fruits per plant.

The reduction in NF observed at the highest NK doses may have occurred probably due to the high rate of flower abortion in the plants that received the highest doses, resulting from the increment in soil electrical conductivity (Leonardo et al., 2008).

Fruit diameter was not affected by the applied treatments and exhibited a mean value of $45.5 \mathrm{~mm}$. On the other hand, fruit length was affected by the fertigation managements at the

Table 2. Summary of the analysis of variance ( $F$ test) for number of fruits (NF), fruit length (FL), fruit diameter (FD), pulp thickness (PT) and fruit production (PROD) of bell pepper fertigated with different doses of NK and fertigation managements

\begin{tabular}{lccccc}
\hline \multirow{5}{*}{$\begin{array}{c}\text { Source } \\
\text { of variation }\end{array}$} & $\mathbf{N F}$ & $\mathbf{F L}$ & $\mathbf{F D}$ & PT & PROD \\
\cline { 2 - 6 } Fertigation & $1.55^{\text {ns }}$ & $1.01^{\text {ns }}$ & $1.29^{\text {ns }}$ & $5.52^{\star *}$ & $1.39^{\text {ns }}$ \\
managements & & & & \\
NK doses & $50.61^{\star *}$ & $0.23^{\star *}$ & $1.99^{\text {ns }}$ & $0.56^{\star *}$ & $24.97^{\star *}$ \\
M x N & $2.34^{*}$ & $0.46^{\star *}$ & $1.03^{\text {ns }}$ & $0.82^{\star *}$ & $5.94^{\star *}$ \\
BLOCK & 2.93 & 3.21 & 1.4 & 6.38 & 0.32 \\
CV (\%) & 13.74 & 10.65 & 7.83 & 7.45 & 16.73 \\
\hline
\end{tabular}

** Significant at 0.01 probability level; *Significant at 0.05 probability level; ${ }^{\text {ns Not significant }}$ 
Table 3. Mean values and regression equations for number of fruits plant ${ }^{-1}$, fruit length, pulp thickness and fruit production of bell pepper fertigated with different doses of NK and fertigation managements

\begin{tabular}{|c|c|c|c|c|c|c|c|}
\hline \multirow{2}{*}{ NK doses } & \multicolumn{3}{|c|}{ Fertigation managements } & \multirow{2}{*}{ NK doses } & \multicolumn{3}{|c|}{ Fertigation managements } \\
\hline & $M_{1}$ & $\mathrm{M}_{2}$ & $\mathrm{M}_{3}$ & & $M_{1}$ & $M_{2}$ & $M_{3}$ \\
\hline \multicolumn{4}{|c|}{ Number of fruits } & \multicolumn{4}{|c|}{ Fruit length $(\mathrm{mm})$} \\
\hline 0 & $7.62 \mathrm{a}^{\star}$ & $7.62 \mathrm{a}$ & $7.62 \mathrm{a}$ & 0 & $52.11 \mathrm{a}$ & $52.11 \mathrm{a}$ & $52.11 \mathrm{a}$ \\
\hline 50 & $14.12 a b$ & $16.00 \mathrm{a}$ & $11.50 \mathrm{~b}$ & 50 & $54.21 \mathrm{a}$ & $56.62 \mathrm{a}$ & $56.96 \mathrm{a}$ \\
\hline 100 & 16.37 b & $20.25 a$ & $17.37 \mathrm{a}$ & 100 & $54.55 \mathrm{~b}$ & $58.31 \mathrm{a}$ & $58.66 \mathrm{a}$ \\
\hline 150 & $16.25 \mathrm{a}$ & $15.00 \mathrm{a}$ & $16.75 \mathrm{a}$ & 150 & $53.03 b$ & $57.67 \mathrm{a}$ & $57.98 \mathrm{a}$ \\
\hline 200 & $15.75 \mathrm{a}$ & $16.25 \mathrm{a}$ & $17.37 \mathrm{a}$ & 200 & $52.26 \mathrm{~b}$ & $60.39 a$ & $55.5 \mathrm{ab}$ \\
\hline \multicolumn{3}{|c|}{ Regression equations } & $\mathrm{R}^{2}$ & \multicolumn{3}{|c|}{ Regression equations } & $\mathrm{R}^{2}$ \\
\hline \multicolumn{3}{|c|}{$\operatorname{NF}\left(M_{1}\right)=-0.00047^{* *} x^{2}+0.130^{* *} x+8.00$} & 0.97 & \multicolumn{3}{|c|}{$\mathrm{FL}\left(\mathrm{M}_{1}\right)=-0.00022^{\star *} \mathrm{X}^{2}+0.042^{\star \star} \mathrm{X}+55.32$} & 0.85 \\
\hline \multicolumn{3}{|c|}{$\mathrm{NF}\left(\mathrm{M}_{2}\right)=-0.00068^{\star \star} x^{2}+0.168^{\star \star} x+8.377$} & 0.87 & \multicolumn{3}{|c|}{$\mathrm{FL}\left(\mathrm{M}_{2}\right)=0.035^{* *} \mathrm{x}+53.48$} & 0.82 \\
\hline \multicolumn{3}{|c|}{$\mathrm{NF}\left(\mathrm{M}_{3}\right)=-0.00037^{\star \star} \mathrm{x}^{2}+0.123^{\star \star} x+7.313$} & 0.95 & \multicolumn{3}{|c|}{$\mathrm{FL}\left(\mathrm{M}_{3}\right)=-0.00048^{\star \star} \mathrm{x}^{2}+0.11^{\star *} \mathrm{x}+52.25$} & 0.99 \\
\hline & $M_{1}$ & $M_{2}$ & $M_{3}$ & & $M_{1}$ & $M_{2}$ & $M_{3}$ \\
\hline \multicolumn{4}{|c|}{ Pulp thickness $(\mathrm{mm})$} & \multicolumn{4}{|c|}{ Fruit production (g plant ${ }^{1}$ ) } \\
\hline 0 & $3.22 \mathrm{a}$ & $3.22 \mathrm{a}$ & $3.22 \mathrm{a}$ & 0 & $287.27 \mathrm{a}$ & $287.27 \mathrm{a}$ & $287.27 \mathrm{a}$ \\
\hline 50 & $3.21 \mathrm{~b}$ & $3.22 b$ & $3.55 \mathrm{a}$ & 50 & $574.35 \mathrm{a}$ & $485.45 \mathrm{~b}$ & $423.42 b$ \\
\hline 100 & $3.13 b$ & $3.25 \mathrm{~b}$ & $3.87 \mathrm{a}$ & 100 & $505.5 \mathrm{~b}$ & $640.77 \mathrm{a}$ & $578.41 \mathrm{ab}$ \\
\hline 150 & $3.11 \mathrm{~b}$ & $3.31 \mathrm{~b}$ & $3.53 a$ & 150 & $473.24 b$ & $562.14 \mathrm{ab}$ & $681.27 \mathrm{a}$ \\
\hline \multirow[t]{2}{*}{200} & $3.08 \mathrm{~b}$ & $3.36 \mathrm{a}$ & $3.34 \mathrm{a}$ & 200 & $404.05 b$ & $593.63 \mathrm{a}$ & $592.51 \mathrm{a}$ \\
\hline & \multicolumn{2}{|c|}{ Regression equation } & $\mathbf{R}^{2}$ & \multicolumn{3}{|c|}{ Regression equation } & $\overline{\mathbf{R}^{2}}$ \\
\hline \multicolumn{3}{|c|}{ PT $\left(M_{1}\right)=-0.00078^{\star \star} x+3.23$} & 0.93 & \multicolumn{3}{|c|}{$\operatorname{PROD}\left(\mathrm{M}_{1}\right)=-0.019^{\star *} \mathrm{x}^{2}+4.127^{\star *} \mathrm{X}+325.81$} & 0.69 \\
\hline \multicolumn{3}{|c|}{ PT $\left(\mathrm{M}_{2}\right)=0.00078^{\star *} x+3.19$} & 0.87 & \multicolumn{3}{|c|}{ PROD $\left(\mathrm{M}_{2}\right)=-0.0162^{\star *} x^{2}+4.620^{\star *} x+294.92$} & 0.92 \\
\hline \multicolumn{3}{|c|}{ PT $\left(\mathrm{M}_{3}\right)=-0.000049^{* *} x^{2}+0.010^{* *} x+3.21$} & 0.86 & \multicolumn{3}{|c|}{$\begin{array}{l}\operatorname{PROD}\left(\mathrm{M}_{2}\right)=-0.0162^{\star *} x^{2}+4.620^{* *} x+294.92 \\
\text { PROD }\left(\mathrm{M}_{3}\right)=-0.0144^{* *} x^{2}+4.608^{* \star} x+267.18\end{array}$} & 0.95 \\
\hline
\end{tabular}

${ }^{*}$ Means followed by the same letters in rows do not differ by Tukey test at 0.05 probability level; $M_{1}$ - Fertigation based on the rate of absorption of the crop; $M_{2}$ - Fertigation based on the monitoring of soil solution electrical conductivity; $\mathrm{M}_{3}$. Fertigation based on the monitoring of the concentration of $\mathrm{N}$ and $\mathrm{K}$ ions in the soil solution

highest proportions of NK (100, 150 and 200\%), with highest values occurring in the managements $\mathrm{M}_{2}$ and $\mathrm{M}_{3}$, which did not differ statistically (Table 3 ).

As to the effects of NK doses, there was a linear response for the management $\mathrm{M}_{2}$ and FL increased as the NK availability increased, exhibiting highest values at the proportion of $200 \%$ NK $(60.48 \mathrm{~mm})$, equivalent to the increment of $13 \%$ in comparison to the FL obtained at the lowest NK dose (53.48 $\mathrm{mm}$ ). For the managements $M_{1}$ and $M_{3}$, the data fitted best to the quadratic model and the highest values were obtained at the proportions of 95 and $115 \%$, with 54.3 and $58.5 \mathrm{~mm}$ for $M_{1}$ and $M_{3}$, respectively (Table 3).

There are not many studies in the literature on the combined effect of $\mathrm{N}$ and $\mathrm{K}$ on the physical characteristics of bell pepper fruits; however, there are reports on the isolated effect of these nutrients on variables of fruit development, such as Marcussi et al. (2004), who evaluated the effect of different doses of NK, ranging from 0 to $150 \%$, and did not find significant response for fruit diameter and length.

Still in this context, Araújo et al. (2009) evaluated the effect of $\mathrm{N}$ fertilization on the bell pepper crop, cv. "All Big", and observed positive response on fruit diameter, although they did not find effect of $\mathrm{N}$ on fruit length, which differs from the results obtained in the present study. Carvalho et al. (2013), working with the same genetic material used in the present study, and Aragão et al. (2012), working with the hybrid cultivar Magali R, observed that high $\mathrm{N}$ doses promote reduction in the bell pepper fruit length and diameter. On the other hand, Melo et al. (2009) observed quadratic effect of $\mathrm{K}$ fertilization on fruit length and diameter of yellow bell pepper, hybrid Zarco.

As to pulp thickness (PT), except for the lowest level of NK $(0 \%)$, there were significant differences between the fertigation managements at the other doses of $\mathrm{NK}$, and the highest values were obtained in $\mathrm{M}_{3}$, except at the doses of 150 and $200 \% \mathrm{NK}$, at which there were no significant differences between the managements $M_{2}$ and $M_{3}$ (Table 3).
According to the regression equations fitted to PT, there was a linear and negative response in the management $\mathrm{M}_{1}$. On the other hand, there was a positive and linear response for $\mathrm{M}_{2}$. Based on the fitted equations for these managements, in the comparison between the extreme doses of NK (0 and 200\%), there was loss of $4.9 \%$ in $\mathrm{PT}$ for $\mathrm{M}_{1}$ and gain of $4.9 \%$ for $\mathrm{M}_{2}$. For $\mathrm{M}_{3}$, the data fitted best to the quadratic model, with highest $\mathrm{PT}$ at the proportion of $102 \% \mathrm{NK}(3.72 \mathrm{~mm})$, equivalent to the increase of $15.8 \%$ in relation to the PT obtained at the lowest dose of NK (3.21 mm) (Table 3).

In a study conducted with $\mathrm{K}$ fertilization in yellow bell pepper, Melo et al. (2009) observed that there was quadratic response for $\mathrm{PT}$ as a function of the increase in $\mathrm{K}$ doses. Wamser (2014), working with bell pepper, "Eppo" hybrid, in hydroponic cultivation, also found effect of $\mathrm{N}$ and $\mathrm{K}$ on this variable.

Fruit production differed between fertigation managements for most doses of NK, except the treatment with absence of these nutrients in the fertigation. The management $\mathrm{M}_{2}$ was superior to the others for the NK dose of 50\%; however, for the other doses, the highest values occurred in $\mathrm{M}_{2}$ and $\mathrm{M}_{3}$, which did not differ statistically (Table 3 ).

These results demonstrate that, for the use of higher NK doses, the adopted fertigation management is determinant to obtain higher production of bell pepper fruits, agreeing with the results obtained by Oliveira et al. (2013), who also found higher production of bell pepper through the monitoring and control of the ionic concentration of the soil solution. Other authors also observed similar responses with other crops, such as tomato (Medeiros et al. 2012; Silva et al., 2013a) and eggplant (Silva et al., 2013b). The monitoring of soil solution allows the application of nutrient as the plants absorb them from the soil solution, resulting in increment in the nutritional efficiency of the crops (Medeiros et al., 2012).

As to the effect of NK doses on fruit production, for the three fertigation managements, the obtained data fitted best to the quadratic model, with highest values at the proportions of 
109,144 and $165 \% \mathrm{NK}$, with maximum productions of 550.2, 583.4 and 646.7 g plant $^{-1}$, for $M_{1}, M_{2}$ and $M_{3}$, respectively. Comparing these values with those obtained in the absence of NK via fertigation, there were increments of 69,133 and $142 \%$, respectively for $M_{1}, M_{2}$ and $M_{3}$ (Table 3).

In a study conducted by Oliveira et al. (2013) also with the bell pepper crop, the authors found higher productions for NK doses of 140, 195 and $244 \%$ for the managements $M_{1}, M_{2}$ and $\mathrm{M}_{3}$. These NK proportions are higher than those observed in the present study, but these authors obtained higher productions, which consequently requires larger amount of nutrients.

In addition, based on the regression equations, for the three fertigation managements, the use of high doses of NK results in the reduction of bell pepper fruit production, which is probably due to the accumulation of salts in the soil. Furthermore, it can be observed that this reduction is more evident in the management $M_{1}$, in which fertigation was based on preestablished doses, with no control of the ionic concentration of the soil solution, as occurred in $\mathrm{M}_{2}$ and $\mathrm{M}_{3}$.

The results obtained in the present study reinforce the importance of more research on the necessity of nutrients in vegetable crops, because it is of fundamental relevance to supply plants with fertilizers that do not lead to an excessive increase in the electrical conductivity of the soil or substrate, promoting the best possible balance between them (Albuquerque et al., 2011).

\section{Conclusions}

1. Fertigation management through the control of the electrical conductivity of the soil solution $\left(\mathrm{M}_{2}\right)$ or the concentration of $\mathrm{NO}_{3}$ and $\mathrm{K}^{+}$ions $\left(\mathrm{M}_{3}\right)$ promoted higher production of bell pepper, in protected environment, compared with the fertigation based on the rate of absorption of the crop $\left(M_{1}\right)$.

2. Fertigation can be performed using the managements $\mathrm{M}_{2}$ or $\mathrm{M}_{3}$, with NK doses of 144 and $165 \%$, respectively, of the concentration recommended for the bell pepper crop in hydroponic system.

\section{Literature Cited}

Albuquerque, F. S.; Silva, E. F. F.; Albuquerque Filho, J. A. C.; Nunes, M. F. F. N. Crescimento e rendimento de pimentão fertigado sob diferentes lâminas de irrigação e doses de potássio. Revista Brasileira de Engenharia Agrícola e Ambiental, v.15, p.686-694, 2011. http://dx.doi.org/10.1590/S1415-43662011000700006

Aragão, V. F.; Fernandes, P. D.; Gomes Filho, R. R.; Santos Neto, A. M.;Carvalho, C. M.; Feitosa, H. Produção e eficiência no uso de água do pimentão submetido a diferentes lâminas de irrigação e níveis de nitrogênio. Revista Brasileira de Agricultura Irrigada, v.6, p.207-216, 2012. https://doi.org/10.7127/rbai.v6n300086

Araújo, J. S.; Andrade, A. P.; Ramalho, C. I.; Azevedo, C. A. V. de. Características de frutos de pimentão cultivado em ambiente protegido sob doses de nitrogênio via fertirrigação. Revista Brasileira de Engenharia Agrícola e Ambiental, v.13, p.152-157, 2009. https://doi.org/10.1590/S1415-43662009000200007

Carvalho, K. S.; Koetz, M.; Silva, T. J. A.; Cabral, C. E. A.; Nunes, J. A. S. Adubação nitrogenada na cultura do pimentão em ambiente protegido. Enciclopédia Biosfera, v.9, p.49-58, 2013.
Castellane, P. D.; Araújo, J. A. C. Cultivo sem solo: Hidroponia. Jaboticabal: FUNEP, 1994. 43p.

EMBRAPA - Empresa Brasileira de Pesquisa Agropecuária. Manual de métodos de análise de solos. 2.ed. Rio de Janeiro: Embrapa CNPS, 1997. 212p.

EMBRAPA - Empresa Brasileira de Pesquisa Agropecuária. Sistema brasileiro de classificação de solos. 2.ed. Rio de Janeiro: EMBRAPA, 2006. 306p.

Ferreira, D. F. Sisvar: Um programa para análises e ensino de estatística. Revista Científica Symposium, v.6, p.36-41, 2008.

Fontes, P. C. R.; Dias, E. N.; Graça, R. N. Acúmulo de nutrientes e método para estimar doses de nitrogênio e de potássio na fertirrigação do pimentão. Horticultura Brasileira, v.23, p.275280, 2005. https://doi.org/10.1590/S0102-05362005000200022

Freitas, K. K. C. Produção, qualidade e acúmulo de macronutrientes em pimentão cultivado sob arranjos espaciais e espaçamentos na fileira. Mossoró: UFERSA, 2009. 110p. Tese Doutorado

IEA - Instituto de Economia Agrícola. <http://www.iea.sp.gov.br/out/ bancodedados.html>. 10 Jan. 2016.

Leonardo, M.; Broetto, F.; Villas Boas, R. L.; Marchese, J. A.; Tonin, F. B.; Regina, M. Estado nutricional e componentes da produção de plantas de pimentão conduzidas em sistema de fertirrigação durante indução de estresse salino em cultivo protegido. Bragantia, v.67, p.883-889, 2008. https://doi.org/10.1590/S0006-87052008000400010

Marcussi, F. F. N.; Godoy, L. J. G.; Villas Bôas, R. L. Fertirrigação nitrogenada e potássica na cultura do pimentão baseada no acúmulo de N e K pela planta. Irriga, v.9, p.41-51, 2004.

Medeiros, P. R. F.; Duarte, S. N.; Silva, E. F. F. Eficiência do uso de água e de fertilizantes no manejo de fertirrigação no cultivo do tomateiro sob condições de salinidade do solo. Revista Brasileira de Ciências Agrárias, v.7, p.344-351, 2012. https://doi. org/10.5039/agraria.v7i2a1563

Melo, A. S. de; Brito, M. E. B.; Dantas, J. D. M.; Silva Júnior, C. D.; Fernandes, P. D.; Bonfim, L. V. Produção e qualidade do pimentão amarelo sob níveis de potássio em ambiente protegido. Revista Brasileira de Ciências Agrárias, v.4, p.17-21, 2009. https://doi. org/10.5039/agraria.v4i1a3

Oliveira, F. A.; Duarte, S. N.; Medeiros, J. F. de; Dias, N. da S.; Oliveira, M. K. T.; Silva, R. C. P.; Lima, K. S. Nutrição mineral do pimentão submetido a diferentes manejos de fertirrigação. Horticultura Brasileira, v.33, p.216-223, 2015. https://doi.org/10.1590/S0102053620150000200013

Oliveira, F. de A.; Duarte, S. N.; Medeiros, J. F. de; Dias, N. da S.; Silva, R. C. P. da; Lima, C. J. G. de S. Manejos da fertirrigação e doses de $\mathrm{N}$ e K no cultivo de pimentão em ambiente protegido. Revista Brasileira de Engenharia Agrícola e Ambiental, v.17, p.1152-1159, 2013. https://doi.org/10.1590/S1415-43662013001100004

Silva, E. M.; Lima, C. J. G. de S.; Duarte, S. N.; Barbosa, F. S.; Maschio, R. Níveis de salinidade e manejo da fertirrigação sobre características da berinjela cultivada em ambiente protegido. Revista Ciência Agronômica, v.44, p.150-158, 2013a. https://doi. org/10.1590/S1806-66902013000100019

Silva, P. F. da; Lima, C. J. G. de S.; Barros, A. C.; Silva, E. M. da; Duarte, S. N. Sais fertilizantes e manejo da fertirrigação na produção de tomateiro cultivado em ambiente protegido. Revista Brasileira de Engenharia Agrícola e Ambiental, v.17, p.1173-1180, 2013 b. https://doi.org/10.1590/S1415-43662013001100007

Wamser, A. F. Concentrações de nitrogênio e potássio na solução nutritiva do pimentão cultivado em substrato sem drenagem. Jaboticabal: UNESP, 2014. 73p. Tese Doutorado 